\title{
Effect of the Xuebijing oral solution on survival of rabbits with acute paraquat poisoning
}

\author{
Song Zu-jun ${ }^{1}$, Chen Gao-fei ${ }^{2 *}$, Ao Guo-kun ${ }^{3}$, Cao Jian-xiao ${ }^{3}$ \\ From 2012 PLA Emergency Medicine Annual Congress \\ Beijing, China. 9-12 November 2012
}

\section{Objective}

To study the effect of the Xuebijing oral solution on survival of rabbits with acute paraquat poisoning.

\section{Methods}

30 New Zealand white rabbits were randomly divided into saline control group(group A) and two treatment groups of $3 \mathrm{ml} / \mathrm{kg}$ (group B) and $10 \mathrm{ml} / \mathrm{kg}$ (group C) of Xuebijing oral solution. All the rabbits were treated with $\mathrm{PQ}$ at $35 \mathrm{mg} / \mathrm{kg}$ through intraperitoneal injection, which would build the model of acute poisoning. Group B and C were treated by gavage with $3 \mathrm{ml} / \mathrm{kg}$ and $10 \mathrm{ml} / \mathrm{kg}$ of Xuebijing oral solution respectively, once a day to maintain. Group A were treated with saline instead.

\section{Results}

The analysis of survival curve showed that the survival rate was not significantly different between group A and B, but group $C$ was significantly higher than group $A$ and $B$ $(\mathrm{P}<0.05)$.

\section{Conclusion}

Large doses of Xuebijing oral solution may improve the survival rate of acute paraquat poisoning.

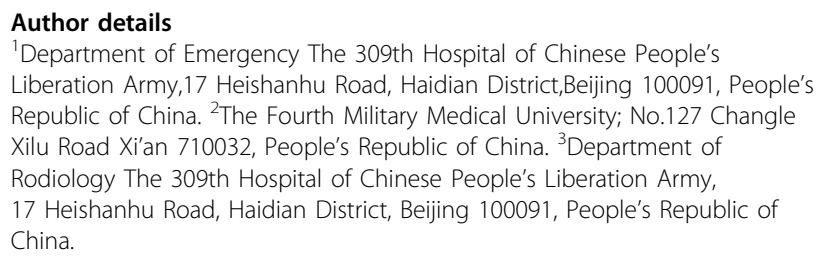

Published: 18 December 2012

\footnotetext{
* Correspondence: chengaofeicoffee@163.com

${ }^{2}$ The Fourth Military Medical University; No.127 Changle Xilu Road Xi'an 710032, People's Republic of China

Full list of author information is available at the end of the article
}

doi:10.1186/1471-227X-12-S1-A6

Cite this article as: Zu-jun et al:: Effect of the Xuebijing oral solution on survival of rabbits with acute paraquat poisoning. BMC Emergency Medicine 2012 12(Suppl 1):A6.
Submit your next manuscript to BioMed Central and take full advantage of:

- Convenient online submission

- Thorough peer review

- No space constraints or color figure charges

- Immediate publication on acceptance

- Inclusion in PubMed, CAS, Scopus and Google Scholar

- Research which is freely available for redistribution

\section{( Biomed Central}

